\title{
PRELIMINARY STUDIES ON THE EFFECTS OF DIFFERENT PROCESSING METHODS ON THE NUTRITIVE VALUE OF SHRIMP WASTE MEAL
}

\author{
ODUGUWA, O.O., FANIMO, A.O., IYAYI* E.A., KALEJAIYE, O.O. AND \\ OYEKOLA O.A. \\ College of Animal Science and Livestock Production, University of Agriculture, Abeokuta, \\ Nigeria, \\ *Department of Animal Science, University of Ibadan, Ibadan, Nigeria: \\ Received 16 May 1998; Accepted 30 September 1998
}

\begin{abstract}
The effects of processing methods viz oven-drying, acid-treatment asd sun-drying on the nutritive value of shrimp waste meal (SWM) was examined. Five purified diets were formulated. A basal diet (Nitrogen-free), a reference diet that contained whole hen's egg and three test diets that contained oven-dried, acid-treated and sun-dried SWM as their protein sources respectively. The reference and test proteins were added to supply $100 \mathrm{~g} / \mathrm{kg}$ crude protein in the different diets at the expense of corn starch in the basal diet. Feed and water were given $a d$ libitum throughout the period of experiment that lasted 14 days. Oven-dried SWM had the highest crude protein and nitrogen-free extracts (NFE) contents $(366.0 ; 85.4 \mathrm{~g} / \mathrm{kg}$ ) compared to the acid- treated $(344.2 ; 59.6 \mathrm{~g} / \mathrm{kg}$ ) and sun-dried SWM $(328.0 ; 42.6 \mathrm{~g} / \mathrm{kg})$. The ether extract of the SWM samples were generally low, no traces of fat could be found in the oven-dried shrimp waste (SW). The sun-dried SW sample had the highest ash contents while the acid-treated SW had the lowest. The oven-dried and sun dried samples consistently contained higher amounts of $\mathrm{Ca}$, $\mathrm{P}, \mathrm{Mg}, \mathrm{K}, \mathrm{Mn}$ and $\mathrm{Na}$ more than the acid treated SW. The latter however contained appreciable quantities of $\mathrm{Fe}, \mathrm{Cu}$ and $\mathrm{Zn}$ in comparison with $S W$ processed by the other two methods. Rats fed the oven-dried SW had the best performance $(P<0.05)$ in terms of body weight. The protein efficiency ratio (PER) and Net protein retention (NPR) showed the same trend as the weight changes. The relative weights of the lungs, kidney, heart, liver and spleen of the experimental
\end{abstract}

animals did not vary significantly $(P<0.05)$ with the dietary treatments.

It was concluded that oven-drying seemed to be the best out of the processing methods employed for shrimp waste in this study but the results are poorer $(P<0.05)$ than those obtained for the reference protein.

Key Words: Processing methods, shrimp waste, Nutritive value.

\section{INTRODUCTION}

There is a significant amount of waste generated by the shrimp processing industry because of the large percentage of shrimp heads, appendages, exoskeleton and soluble components lost during the various processing operations. Not less than 3000 metric tonnes of shrimp waste is estimated to be produced in a year in South Western Nigeria alone (Nigeria Institute of Occanography and Marine Research (NIOMR) Report 1991).

This product has high potentials as a feed resource. Rosenfeld et al. (1997) reported that shrimp waste could partially or totally replace the use of soyabean meal in-broiler dicts without negatively affecting bird performance or carcass quality. Investigations into the replacement value of the product for fish meal in broiler and weaner pig diets showed that it can replace $66 \%$ of the protein supplied by fish meal in practical dicts (Fanimo and Oduguwa 1994; Fanimo et al., 1996). High level of chitin were implicated in poor performance of the experimental animals on high levels of shrimp waste meal. The workers further observed that the negative effects of chitin seemed to be more pronounced on younger birds which recorded high mortality. On autopsy, the crop of the 
ODUGUWA ET AL

TABLE 1: COMPOSITION OF EXPERIMENTAL DIETS $\mathrm{g} / \mathrm{Kg}$ )

\begin{tabular}{|c|c|c|c|c|c|}
\hline Ingredients & Basal diet & $\begin{array}{l}\text { Reference } \\
\text { Whole Hen's egg }\end{array}$ & $\begin{array}{l}\text { Oven-dried } \\
\text { SWM }\end{array}$ & $\begin{array}{l}\text { Acid treated } \\
\text { SWM }\end{array}$ & $\begin{array}{l}\text { Sun-dried } \\
\text { SWM }\end{array}$ \\
\hline Com Staru & 650.0 & 489.1 & 345.4 & 328.4 & 318.9 \\
\hline Glucose & 50.0 & 50.1 & 50.0 & 56.0 & 50.0 \\
\hline Sucrose & 100.0 & 100.0 & 100.0 & 100.0 & 100.0 \\
\hline \multicolumn{6}{|l|}{ Non-nutritive } \\
\hline cellulose & 50.0 & 50.0 & 50.0 & 50.0 & 50.0 \\
\hline Vegetable oil & 100.0 & 100.0 & 100.0 & 100.0 & 100.0 \\
\hline Premix & 20.0 & 20.0 & 20.0 & 20.0 & 20.0 \\
\hline Oyster shell & 10.0 & 10.0 & 10.0 & 10.0 & 10.0 \\
\hline Bone meal & 20.0 & 20.0 & 20.0 & 20.0 & 20.0 \\
\hline Whole Hen's egg & $\cdot$ & 160.1 & $\cdot$ & - & - \\
\hline Shrimp waste meal & $\cdot$ & - & 304.0 & 321.8 & 331.0 \\
\hline Total & 1000 & 1000 & 1000 & 1000 & 1000 \\
\hline
\end{tabular}

*Premix supplied the following per $\mathrm{kg}$ of feed.

Vitamin $A=8000 \mathrm{IU}$; Vit. $\mathrm{D}_{3}=1500 \mathrm{JU}$; Vit $\mathrm{E}=40 \mathrm{mg}$; Vit $\mathrm{B}_{2}=6 \mathrm{mg}$; Vit $\mathrm{B}_{3}=35 \mathrm{mg} ; \mathrm{Vit}_{6}=3.5 \mathrm{mg}$; choline chloric $=300 \mathrm{mg} ;$ Manganese $=100 \mathrm{mg} ; \mathrm{Imn}=50 \mathrm{mg} ;$ Copper $=10 \mathrm{mg} ;$ Iodine $=1.55 \mathrm{mg} ;$ Selenium $=0.10 \mathrm{mg} ; \mathrm{Vit} \mathrm{K} 3$ $=2.5 \mathrm{mg} ;$ Calcium pantothenate $=10 \mathrm{mg} ;$ Vit. $B_{12}=0.025 \mathrm{mg} ;$ Zinc $=45 \mathrm{mg} ;$ Cobalt $=0.225 \mathrm{mg} ;$ Vit. $B_{1}=2.0 \mathrm{mg}$. Biotin $=0.05 \mathrm{mg}$, Folic acid $=1.00 \mathrm{mg}$

TABLE 2: CHEMICAL COMPOSITION OF WHOLE HEN'S EGG, OVEN-DRIED, ACID-TREATED AND SUN-DRIED SHRIMP WASTE MEAL ON DRY MATTER BASIS

*Whole Hen's egg Oven-dried SWM Acld-1realed SWM Sun-dried SWM

\begin{tabular}{|c|c|c|c|c|}
\hline \multicolumn{5}{|l|}{ Proximate $(\mathbf{g} / \mathbf{k g})$} \\
\hline Crude protein & 621.6 & 366.0 & 344.2 & 338.9 \\
\hline Ether extract & 211.2 & - & 11.1 & 9.0 \\
\hline Crude Fibre & - & 133.2 & 138.5 & 117.0 \\
\hline Ash & 34.0 & 416.7 & 347.0 & 491.6 \\
\hline Nitrogen free extracts & 133.2 & 85.4 & 59.6 & 42.6 \\
\hline Chitin & & 101.0 & ND & 98.2 \\
\hline \multicolumn{5}{|l|}{ Minerals } \\
\hline $\mathrm{Ca}(\mathrm{g} / \mathrm{kg})$ & & 162.5 & 59.3 & 157.7 \\
\hline$P(g / k g)$ & & 3.7 & 3.3 & 4.5 \\
\hline $\mathrm{Mg}(\mathrm{g} / \mathrm{kg})$ & & 7.0 & 1.2 & 6.9 \\
\hline$K(g / k g)$ & & 1.2 & 0.03 & 0.8 \\
\hline Mn (mg/kg) & & 34.2 & 28.1 & 37.2 \\
\hline $\mathrm{Na}(\mathrm{mg} / \mathrm{kg})$ & & 1433.1 & 312.7 & 2209.9 \\
\hline $\mathrm{Fe}(\mathrm{mg} / \mathrm{kg})$ & & 149.8 & 154.6 & 181.4 \\
\hline $\mathrm{Cu}(\mathrm{mg} / \mathrm{kg})$ & & 29.7 & 32.6 & 30.4 \\
\hline $\mathrm{Zn}(\mathbf{m g} / \mathbf{k g})$ & & 23.0 & 32.6 & 27.4 \\
\hline
\end{tabular}

*Mineral content of whole hen's egg not determined 
dead birds were found to be abnormally engorged with feed which was an indication of low ability of the birds to digest the shrimp waste meal. The metabolic studies also showed significant reduction in the retention of protein when high levels of SWM was fed. Oduguwa et al., (1998) reported that SWM protein was inferior to that of maggot meal and whole hen's egg. Futhermore, they observed that rats fed purified diets with SWM as the only source of protein lost weight.

It is obvious from the foregoing that although SWM has high potentials, its level of utilization is low when compared to conventional animal protein sources. The authors indicted chitin as a major source of low utilization of SWM protein. Chitin is abundant in the exosketeton of shrimp and SWM contains high amounts of this compound. Chitin is a homo-polymer of $\mathrm{N}$-acetyl- B-D-glucosamine joined by $\left(\begin{array}{ll}1 & 4\end{array}\right)$ glycosidic linkage (MacDonald et al. 1991). This makes it to be similar in many respects to cellulose which is also a structural material. Chitin is not readily digestible by monogastric animals. BoGohl (1975) reported that about $10 \%$ of the crude protein in whole shrimp meal orginates from chitin while up to $50 \%$ of the nitrogen in the waste originates from chitin which he described as nearly indigestible. He opined that crude protein figure of analysis of shrimp meal should be corrected for the crude protein fraction contributed by the chitin present.

A processing method for SWM that would eliminate or reduce the negative effects of chitin on the animals will be a major break through in the increased use of this product. It is therefore the object of this study to treat shrimp meal using methods such as acid treatment (HCL) oven-drying and then to evaluate with rats the protein quality of the processed shrimp meals.

\section{MATERIALS AND METHODS}

The experiment was conducted at the experimental rat house, Department of Animal Science, University of Ibadan where the prevailing climate is humid tropical.

\section{Experimental Protocol}

Thirty albino rats of the Winster strain within the same colony were obtained from the rat unit of the Department of Physiology, Lagos University Teaching Hospital (LUTH) Lagos. Five purified diets were formulated as follows: Diet 1 was the basal diet (Nitrogen free), Diet 2 contained whole hen's egg as its only source of protein. This was the reference diet. Diet 3, 4 and 5 contained oven-dried, acid-treated and sun-dried shrimp waste (SW) as their protein sources respectively. The reference and test proteins were added to supply $100 \mathrm{~g} / \mathrm{kg}$ crude protein in the different. diets at the expense of corn starch in the basal diet (Table 1).

The reference and the test proteins were processed in the following manner before incorporating them into the various diets.

\section{Whole egg:}

Fresh egg locally purchased were cooked slightly in aluminium pot for $\mathbf{1 0}$ minutes. They were cooled in a bath of water immediately, peeled and the yolk and egg white were macerated dried in the oven at $42^{\circ} \mathrm{C}$ for 48 hours, thoroughly mixed together, and ground in a laboratory mortar and pestle.

\section{Shrimp waste meal:}

Shrimp waste was obtained fresh from Ocean Fisheries Ikorodu, Lagos State Nigeria. The batch was divided into three for processing. The different processing methods employed were:

\section{Oven-drying:}

A portion of the SW was oven-dried at a temperature of $65^{\circ} \mathrm{C}$ for 48 hours and then milled in a kitchen blender.

\section{Acid treatment:}

Another portion of the SW was soaked in $10 \%$ HCL for about 10 minutes after this, the acid solution was drained out and the shrimp waste was washed gently with clean water, air dried and milled.

\section{Sun-drying:}

The SW was spread thinly on a concrete slab and was allowed to dry for 3 days after. which it was milled. The shrimp waste 
samples were analysed for their proximate and mineral constituents using the A.O.A.C. (1984) methods.

Six rats were allotted to each diet on weight equalization basis. The rats were housed individually in stạinless steel metabolic cages. Records of weight and feed intake were taken throughout the trial which lasted 14 days. Feed and water were given ad libitum during this period. Records of faecal output were also taken daily for the last 7 days of the experiment. Protein intake and output were calculated to determine the apparent crude protein digestibility for each diet except the basal diet. Protcin efficiency ratio (PER) and net protein retention (NPR) were calculated using the formulac:

$\begin{array}{ll}\text { PIR = } & \frac{\text { gain in body weight }(\mathrm{g})}{\text { protein consumed }(\mathrm{g})} \\ \text { NPR = } & \text { gain in weight of test group (g) } \\ & \frac{\text { - weight loss of non protein group (g) }}{\text { protcin consumed (g) }}\end{array}$

At the end of the experiment, the rats were slaughtered by cervical dislocation, and the lungs, kidncy, heari, liver and spleen were removed immedialcly and weighed fresh. These weights were laler expressed as percentage of the final body weight. The data were subjected to analysis of variance using the randomiscd complete bleck design (Steel and Torric 1980). Means that were significant were separated using the least significant difference.

\section{RESULTS AND DISCUSSION}

\section{Chemical composition of processed shrimp waste samples}

Table 2 shows the proximate composition and minicral assay of the processed SW samples and the reference protein (whole hen's egg). Oven-dried shrimp waste meal (SWM) had the highest crude prolein (CP) and Nitrogen frec extracts (NFE) contents $(366.0 ; 85.4 \mathrm{~g} / \mathrm{kg}$ ) compared to the acid-treated $(344.2 ; 42.6 \mathrm{~g} / \mathrm{kg})$. The ether cxtract contents of the SWM were generally low; in fact no traces of fat could be found in oven dried samples. Shrimp does not seem to contain high amount of oil more so the discarded parts that constitute SW are expected to contain less oil. The low values of ether extract obtained in this study agree with earlier studies which reported values that ranged from 7.5 $90.0 \mathrm{~g} / \mathrm{kg}$ ether extract (Fanimo et. al 1997; Oduguwa et al, 1998).

The sun-dried samples had the highest ash contents while the acid-treated SW had the lowest. This may be because the acid used was able to dissolve or precipitate some minerals that are attached to the exoskeleton. Levels of mineral elements such as $\mathrm{Ca}, \mathrm{P}$ and $\mathrm{Mg}$ are known to be high in shrimp exoskeleton because they are deposited to strengthen the structure. Sun-drying could not have effected any substantial removal of these mineral elements and this may account for the high ash content of the sun-dried samples. The difference in the crude fibre contents for the various SW samples were not substantial. The reference protein did not contain any crude fibre. It had high crude protcin as cxpected (621g.kg) and high fat $(211.1 \mathrm{~g} / \mathrm{kg})$ contents. The whole egg contained 34.0 and $133.2 \mathrm{~g} / \mathrm{kg}$ of ash and NFE respectively.

The oven-dried and sun-dried samples consisiently contained higher amounts of $\mathrm{Ca}$, $\mathrm{P}, \mathrm{Mg}, \mathrm{K}, \mathrm{Mn}$ and $\mathrm{Na}$ more than the acidtreated SWM. The latter however contained appreciable quantities of $\mathrm{Fe}, \mathrm{Cu}$ and $\mathrm{Zn}$ in comparison with SWM processed by the other two methods. The mineral assay is in consonance with results obtained for ash determined where the acid-treated SWM had the lowest value. The acid used most probably precipitated or completely dissolved the mincrals which apparently went with the drained water. It is even clear from the results that highly soluble minerals such as $\mathrm{Na}$ and $\mathrm{K}$ recorded very sharp drop in their values in acid-treated SW.

\section{Performance}

Table 3 presents the performance characteristics of experimental rats. The final live weights of rats on reference diet was the highest followed by those on oven-dried, 


\begin{tabular}{|c|c|c|c|c|c|}
\hline & $\begin{array}{l}\text { Reference } \\
\text { Whole Hen's ets }\end{array}$ & $\begin{array}{l}\text { Oren-dried } \\
\text { SWM }\end{array}$ & $\begin{array}{l}\text { Acid-trealed } \\
\text { SWM }\end{array}$ & $\begin{array}{l}\text { Smin-dyled } \\
\text { SWM }\end{array}$ & S5M \\
\hline \multicolumn{6}{|l|}{ Parnimeter } \\
\hline Initial weight (g) & 71.0 & 70.6 & 67.8 & 67.7 & 0.79 \\
\hline Final weight (g) & $84.1^{\mathrm{a}}$ & $74.0^{6}$ & $60.6^{\mathrm{d}}$ & $65.8^{\mathrm{c}}$ & 4.46 \\
\hline Weight gain $g /$ rat/week & $6 S^{3}$ & $1.7^{b}$ & $-3.6^{\mathrm{d}}$ & $-0.9^{\mathrm{c}}$ & 2.16 \\
\hline Feed intake g/rat/week & $43.0^{2}$ & $32.0^{\mathrm{c}}$ & $36.6^{\mathrm{b}}$ & $28.6^{\mathrm{d}}$ & 3.16 \\
\hline Protein intake $g / r a t /$ week & $4.8^{2}$ & $3.9^{c}$ & $4.0^{b}$ & $3.0^{\mathrm{c}}$ & 0.24 \\
\hline Protein efficiency (PER) & $1.4^{2}$ & $0.44^{b}$ & $-0.89^{c}$ & $-0.32^{c}$ & 0.48 \\
\hline NET profein retention (NPR) & $1.4^{*}$ & $0.52^{b}$ & $-0.76^{\mathrm{C}}$ & $-0.18^{\mathrm{c}}$ & 0.47 \\
\hline \multicolumn{6}{|c|}{ Apparent protein đigestibility } \\
\hline$(g / \mathbf{k g})$ & $860.0^{2}$ & $564.3 c$ & 850.7 & $608.0 b$ & 76.9 \\
\hline
\end{tabular}

a,b,c: Treatment means on the same row without a common superscript are significantly different $(P<0.05)$

sun-dried and acid treated SW in that order. All these weights were significantly different from one another $(P<0.005)$. Rats on acid-treated SW and sun-dried SW lost weight at the end of the experiment. This observation is consistent with the earlier studies (Oduguwa et al., 1998) where rats on $S W$ as the only source of protein lost weight. It was however opined that the experimental rats used for the above experiment were so tender $(37.20 \pm 1.8 \mathrm{~g}$ average initial weight) and that this could have aggravated the negative effects of chitin on the utilization of the $S W$ protein by the rats. The rats used in this study were quite older $(69.29 \pm 0.79 \mathrm{~g}$ average intial weight), but they still lost weight on sun- dried and acid-treated SW, although there was a marginal weight increase for the rats on oven-dried SW. The fact still remains that whether young or old, there was a factor probably chitin that impaired the utilization of SWM in the rats. The results obtained for oven-dried samples were significantly lower than the mean weight gain values of rats on the reference protein diet $(\mathrm{P}<0.05)$. Other processing methods should be tried solely or along with these methods to see whether there will be an improvement. Exogenous enzyme supplementation may be the solution to this problems, since fibrous polysaccharides are known to be rendered utilizable by exogenous addition of enzymes to the feeds (Friesen $e$ al, 1992).

Acid treatment induced the highest $(P<0.05)$ feed consumption rate among the processing methods. The high crude fibre content of the acid-treated sample could have been a contributory factor. The protein intake followed basically the same trend as the feed intake. Protein efficiency ratio (PER) and Net protein retention (NPR) revealed the same trend as the weight changes where the oven dried samples were the best utilized SWM. Rats fed acid- treated and sun-dried $S W$ had negative values of PER and NPR. This further underscores the inability of the rats to properly utilize the $S W$ protein even after the processing. The apparent protein digestibility obtained for rats on acid-treated SW which was significantly higher $(P<\mathbf{0 . 0 5})$ than all other treatments except the reference protein did not reflect in the weights.

The relative weights of the lungs, kidneys, heart, liver and spleen of the experimental animals are presented in Table 4. These weights did not vary significantly $(P>0.05)$ with the dietary treatments. Earlier studies have revealed an increased $(P<0.05)$ relative weight of gizzard, liver and abdominal fat in broilers with increasing level of SWM in their diets (Fanimo et al, 1996). This trend was not noticeable in this present study. 


\begin{tabular}{llllll}
\hline & $\begin{array}{l}\text { Reference } \\
\text { Whole Hen's egg }\end{array}$ & $\begin{array}{c}\text { Oven-dried } \\
\text { SWM }\end{array}$ & $\begin{array}{c}\text { Acid-treated } \\
\text { SWM }\end{array}$ & $\begin{array}{c}\text { Sun-dried } \\
\text { SWM }\end{array}$ & $\begin{array}{c}\text { SEM } \\
\text {-Organs }\end{array}$ \\
Lungs & 1.12 & 1.13 & 1.25 & 1.21 & 0.08 \\
Kidney & 1.36 & 1.24 & 1.61 & 1.51 & 0.15 \\
Heart & 0.86 & 0.97 & 1.05 & 1.03 & 0.04 \\
Liver & 3.77 & 3.04 & 3.20 & 3.31 & 1.00 \\
Spleen & 0.88 & 0.78 & 0.98 & 0.97 & 0.03 \\
\hline
\end{tabular}

Treatment means on the same row without a common superscript are not significantly different $(P>0.05)$.

* Expressed as percentage of final live weight

In conclusion, oven-drying seemed to be the best out of the processing methods employed for shrimp waste in this study, but the results are not encouraging when the values are compared with those obtained for the reference protein. The preliminary nature of this study is also noted. There might be need for verification of this study using broilers.

\section{ACKNOWLEDGEMENT}

The authors are grateful to the Management of Ocean Fisheries Ikorodu, Lagos, Lagos State for supplying the SW used for this study.

\section{REFERENCES}

A.O.A.C. (1984). ASSOCIATION OF ANALYTICAL CHEMISTS. Official Methods of Analysis 12 th edition, Washington D.C.

BOGOHL (1975). Tropical Fceds: Feeds information summaries \& Nutritive values. FAO feed information Centrc Animal Production \& Health Division FAO Rome.

FANIMO, A.O. AND ODUGUWA, O.O. (1994). Replacement of fish meal with shrimp waste meal in weaner pig diet. Nig. J. Agric.

Sc. In press.

FANIMO, A.O., MUDAMA, E., UMUKORO, T.O. AND ODUGUWA, O.O. (1996). Substitution of shrimp waste meal for fish meal in broiler chicken rations. Trop. Agric. (Trinidad) 73(2): $201-205$.
FRIESEN, O.D., SUENTER, W. MARQUARDT, R.R. AND ROTTER, B.A (1992). The effect of enzyme supplementation on the Apparent Metabolizable Energy and Nutrient Digestibilities of Wheat, Barley, Oats and Rye for the young broiler chick. Poult. Sci. 71: 1710 - 1721.

MACDONALD, P., EDWARDS, R.A. AND GREEN-HALGH, J.F.D. 1991. Animal Nutrition 4th Edition McGraw Hill Book Company New York.

NIOMR. 1991. Nigerian Institute of Oceanography and Marine Research. Highlights of achievements in the last 30 years by NIOMR J.G. Tobor Editor 23 pp.

ROSENFELD, D.J., GERNAT, A.G., MARCANO, J.D., MURILLO, J.G., LOPEZ, G.H. AND FLORES, J.A. (1997). The effect of using different levels of shrimp meal in Broiler diet. Poult. Sci. 76: 58 - 587.

ODUGUWA, O.O., FANIMO, A.O., ONIFADE, A.A. AND ARIJE, A. 1998. The nutritive value of shrimp waste meal and fly larvae (maggot meal) (In press).

STEEL, R.G.D. AND B.G. TORRIE (1980). Principles and Procedures of Statistics. A biometrical approach 2nd edition McGraw Hill New York. 